\title{
On history and salvation in Emmanuel Levinas and Ernst Bloch ${ }^{1}$
}

\author{
Salomon J Terreblanche \\ Department of Philosophy \\ University of Johannesburg
}

\begin{abstract}
This article explores the tension between history and salvation as theme in contemporary social and humanist philosophy. Special reference is made to Emmanuel Levinas' work in order to delineate the scope of the questions involved, and to critically elucidate the position on history, death and hope in new-Marxist philosopher Ernst Bloch. The article then illuminates Levinas' phenomenological account of fecundity, parenthood, patience and institutional justice as hopeful moments that are contained in his philosophy on history
\end{abstract}

\section{INTRODUCTION}

Making sense of history's indifference represents an underlying ethical concern in humanist philosophy of the 20th century. This article investigates the field of tension between the realisation of historical indifference and hope for the maintenance of human dignity, with special reference to the philosophy of Emmanuel Levinas (1906-1995). What contributes to Levinas's unique place within the landscape of contemporary humanist and moral philosophy is that in spite of his gloomy account of the indifference of history (and the violence of being), the thought of human dignity does not succumb in the face of the indifference of history. The interpersonal relationship institutes an order where time, alleviated above the impersonal time of history, realises the possibility of novelty, renewal and repair.

\footnotetext{
${ }^{1}$ This article is based on research done for my doctoral dissertation (Reconsidering humane social ideals - Prophetic hope in Emmanuel Levinas and Ernst Bloch) completed at the Institute of Philosophy, Catholic University of Leuven (Belgium) in 2005. This contribution is thematically related to my article, "Todorov, Levinas and anti-totalitarian humanism: A perspective on contemporary utopian thought", published in HTS 63(1), 301-325. The financial assistance of the National Research Foundation (NRF) towards this research is hereby acknowledged. Opinions expressed and conclusions arrived at, are those of the author and are not necessarily to be attributed to the NRF.
} 
The article starts with an elucidation of the conceptual and normative scope within which the question as to the tension between history and salvation unfolds ( $\mathrm{Sec} 2$ ). It is shown how Levinas's position on death holds significant implications for his thought on subjectivity in history. In Section 3 Levinas is brought into dialogue with Ernst Bloch (1885-1977) regarding the theme of subjectivity, history and salvation. In the history of modern philosophy, Bloch has proved to be essential as a transitional figure between $19^{\text {th }}$ Century Marxist philosophy and $20^{\text {th }}$ century new-Marxist critical theory. Bloch was one of the first figures who undertook to break out of the orthodoxies of $19^{\text {th }}$ century Marxism. He attempted to retrieve and substantiate the credibility of utopian moments in the traditions of idealist and Marxist philosophy, including its optimistic account of history. The question arises as to how Bloch's utopian philosophy meets the ethical challenge Levinas sets with his uncompromising emphasis on the dignity of the human individual, which ought not to be sacrificed for the sake of historical ideals. Section 3 investigates this question and illustrates the ambiguity of Bloch's position in this regard. Levinas's position of the possibility of salvation from the indifference of history forms the focus of Section 4. Fecundity, patience and institutional justice are elucidated as three perspectives within which the subject transcends its own mortality and rises above history's indifferent march.

\section{THE TENSION BETWEEN HISTORY AND SALVATION IN LEVINAS}

Levinas's perspective on the relationship between history and salvation shows an evolution from his early to his mature writings. In his early works Existence and existents and Time and the Other [both from 1947] - history appears to be conceived of as the relationship between humans and the condition of time. ${ }^{2}$ Thus, what is called history is already on the plane of salvation from the there is. ${ }^{3}$ In Totality and infinity [1961], in contrast, a tension

\footnotetext{
${ }^{2}$ See Levinas (1987:79): "The condition of time lies in the relationship between humans, or in history". Subsequently the following abbreviations will be used for reference to texts by Levinas: AT (Alterity and transcendence); DF (Difficult freedom); EE (Existence and existents); EN (Entre Nous. Thinking of the Other); GDT (God, death, and time); GM (Of God who comes to mind); $\mathrm{OB}$ (Otherwise than being or beyond essence); RB (Is it righteous to be?); TI (Totality and infinity. Essay on exteriority); TeO (De totaliteit en het Oneindige. Essay over de exterioriteit); TO (Time and the Other). Further details appear under Works consulted.

${ }^{3}$ Levinas's notion of the there is [il $y$ a] is the pivotal theme of his early philosophical work, and remains important in his mature and later works. By there is Levinas refers to a primordial, fundamental layer of being, which precedes being as light and intelligibility. See EE (57-64) and TO (44-57) in this regard. What we call the subject originally finds itself stuck to anonymous being or captured in what Levinas refers to as "the being without beings". It is only in the approach of the fellow human being that the self is liberated from the fatality of the there is, that light becomes possible, and that language and meaning open up (TI 92, 262, 297).
} 
emerges between history and salvation. The meaning of history then fluctuates between the plane of the there is (totality) and the plane of salvation.

"History is worked over by the ruptures of history, in which a judgement is borne upon it. When man truly approaches the Other he is uprooted from history" (TI 52).

In Totality and infinity, history is portrayed as the indifferent march of events; as the supra-individual forces that threaten to annihilate the subject. ${ }^{4}$ In the preface Levinas refers numerous times to the conflict between the "eschatology of messianic peace" and the "ontology of war". ${ }^{5}$ History is associated with an ontological plane that has the characteristic of indifference, where being manifests itself as "war", and where the human subject is made subordinate to forces that preside over it. The indifference of the there is (which, in the early works characteristically is an a-moral indifference) now takes on an ethical significance. Characteristic of Levinas's humanism is that he does not allow the instance that "decentres" the subject to have the last word. In Levinas's mature and later writings, historical totality is portrayed as an instance which threatens to annihilate and ridicule the humanity of the human subject. As Catherine Chalier (1998:282) remarks: "The judgement of history ... remains necessarily unjust in relation to the singularity of each person, and indifferent to his or her fate."

Such outlook on history holds direct consequences for the way in which one will conceive of the meaning of life in its relation to human mortality. If there is no grand plan to history, there is no such thing as a meaningful death for the sake of history. ${ }^{6}$ In the midst of the indifference of history, the human individual is confronted with his/her own mortality. ${ }^{7}$ The question of the possibility of salvation within history becomes a question of how the individual subject comes to meet its own death.

In Totality and Infinity Levinas treats the problem of individual mortality in the light of the tension that occurs between the totality of history and

\footnotetext{
${ }^{4}$ We can recognise this outlook on history in the opening pages of Totality and Infinity: "The ontological event that takes form in this black light ['noire clarté] is a casting into movement of beings hitherto anchored in their identity, a mobilization of absolutes, by an objective order from which there is no escape. The trial by force is the test of the real" (TI 21).

${ }^{5} \mathrm{TI}$ (22). See also De Boer (1976:57-94 ) for a good analysis of the tension between ontology and eschatology in Levinas's mature work, and Chalier's (1998) article on the relation between history and Messianism in Levinas.

${ }^{6}$ See also DF (227): "[O]ne is wrong to expect justice from history”.

${ }^{7}$ As in Time and the Other (71-77), Levinas in his mature work remains agnostic on the question as to what awaits the human subject in death, which is to say, he continues to stress that death is the unknown. See TI (234) and AT (153).
} 
individual interiority. The notion of "interiority" is connected with what Levinas calls the "atheism" of the subject. To the human subject there is a core of existence that stands separate from the totality of being. Levinas stresses "that beings exist in relationship, to be sure, but on the basis of themselves and not on basis of the totality". ${ }^{8}$ Now, the totality of history shows itself as indifferent to this separated existence of the individual, wherein, also, the human dignity of the subject resides, and it threatens to swallow its separateness and place it under erasure. The subject finds a first haven against this threat of history by withdrawing itself into its interior life. "Interiority institutes an order different from historical time in which totality is constituted, an order where everything is pending, where what is no longer possible historically remains always possible" (TI 55). Interiority allows the subject freedom with regards to the apparent fatality of events in the public realm.

Now, the existence of the separated subject is characterised also by mortality. Death threatens as an instance that would make a definite end to the freedom of the subject and that would come to crush the haven against the totality that interiority allows it. Death threatens as the point at which one will start to coincide with the totality of history.

In the totality of the historiographer the death of the other is an end, the point at which the separated being is cast into the totality, and at which, consequently, dying can be passed through and past, the point from which the separated being will continue by virtue of the heritage his existence has amassed.

When one dies, the dates of one's birth and death are written in a death register and inscribed on a tombstone. Death thus marks the point at which one's existence is inserted into the totality of the historiographer. According to Levinas, the subject's attitude in the face of its own death is characteristically one of refusal to be reduced to its place within the totality of history. ${ }^{9} \mathrm{He}$ contends that the refusal to be inserted into the totality of history, "is what was expressed, always negatively, by the idea of the eternity of the soul: the dead one's refusal to fall into the time of the other, the personal time free from

\footnotetext{
${ }^{8} \mathrm{TI}$ (23). Alain Finkielkraut explains the anti-totalitarian significance of Levinas's notion of "atheism": "By saying, in effect, that the subject, though part of the whole, exists as a separate being and derives his existence from within, Levinas's thought rests uneasily on what the modern age calls morality and enlightenment. It is the site of an invaluable slippage, allowing us to address the totalitarian experience in a language not its own and to confront that experience with something other than its own means or values" (1997:71).

${ }^{9}$ See also Burggraeve (1986:206-207) in this regard.
} 
common time. If common time were to absorb the time of the 'l' death would be the end" (TI 57). Levinas thus appears to be sceptical of the idea that one overcomes one's mortality in one's work. When the subject is identified with its work entirely, and reduced to, the personal time of the self is overlooked, and then the self is absorbed without residue in the common time of history. Moreover, the will of the self - expressed in work - undergoes alienation in work. Since it is not within the powers of the subject to control the meaning that its work will attain, work can attain from others a meaning alien to the will of the subject. "The other can dispossess me of my work, take it or buy it ... The work is destined to this alien Sinngebung from the moment of its origin in me" (TI 227). The subjective will retreats in the face of the possibility of such alienation (TI 228). From a Levinasian point of view, a valorisation of life's work as a means to overcome mortality would seem like a justification of a fatalistic view of history.

Against the back-ground of this scepticism about the value of life's work, it is perhaps surprising that Levinas shows appreciation for the presence of the idea of the valorisation of life's work in the philosophy of Ernst Bloch. Levinas left behind two appreciative essays on the thought of Bloch (GM 33-42; GDT 92-105), where he expresses enthusiasm for his philosophy of hope, and emphasises that he finds in Bloch an ally for his opposition of Martin Heidegger's philosophy. Throughout his philosophical oeuvre, Levinas engaged in questioning and challenging the idea in Heidegger that time and the meaning of being are derived from the horizon of one's own mortality. As Levinas remarks on Heidegger: "Time owes its originality, as a temporalisation that starts from the future, to the finitude of human existence destined to being. Being-towards-death is what is most proper to man" (GDT 99). Levinas is thus noticeably not at ease with the primordial significance that the own death (i.e. Dasein's death) attains in Heidegger's thought. What Levinas finds plausible in Bloch, is the manner in which, instead of deriving time from the horizon of mortality, death rather attains its meaning in perspective of the infinitude of time (GDT 104). Moreover, in Bloch the emotion that characterises the individual's death is not anxiety for one's own death, but instead a melancholy that the work of one's life is incomplete, and the meaning of time not fulfilled. ${ }^{10}$ The next section takes an in-depth look at Bloch's position of death, and critically discerns its plausibility from the perspective of Levinas's ethical thought.

${ }^{10}$ See also Terreblanche (2003:19-23) in this regard. 


\section{DEATH AND LIFE'S WORK: PUTTING BLOCH TO A LEVINASIAN QUESTION}

We encounter an intriguing disagreement between Levinas and Bloch with regard to the attitude with which the individual subject meets its own death. Still, on the surface their reflections on the theme show some extent of convergence: For Bloch - as for Levinas - the human individual characteristically meets death with an attitude of refusal. Bloch expresses the emotion with which the subject meets death in the dictum non omnis confundar: let me not be utterly confounded. ${ }^{11}$ In contrast to Levinas's contention that scepticism with regards to work is what is at stake in this refusal, for Bloch this refusal is connected with his valorisation of life's work i.e. the individual's contribution to history - at the heart of his philosophy. What non omnis confundar expresses is hope that the work of one's life has made a contribution that will exceed the limited span of one's lifetime ( $\mathrm{PH}$ 1161-1162), and, more specifically, hope that within the greater march of time the work of one's life contributes to building a humane society. ${ }^{12}$ Because the humanum, which the work of life latently aims at, is not realised within one's lifetime, one meets one's own death with an emotion of melancholy. The fear of dying is the fear of leaving the work of one's life incomplete (PH 1164). Bloch's philosophy expresses hope that there is something to human history which exceeds the individual and offers him/her consolation in the face of his/her mortality (see SU 234, 240).

When one looks at these ideas from a Levinasian perspective, Levinas's stress on the irreplaceable dignity of the human individual gives rise to some extent of scepticism about the value of work of life. This compels us to ask, critically, whether Bloch's appreciation of life's work implies that he remains oblivious to the threat that the totality of history poses to the dignity of the individual subject. Is the implication that the death of the individual is a sacrifice paid for the sake of history? Does Bloch's notion of death, and his valorisation of life's work, betray a certain dialectical indifference to the human individual at the heart of his thought?

\footnotetext{
${ }^{11}$ Bloch (1986:1176). Subsequently the following abbreviation will be used to refer to texts by Bloch: SU (The Spirit of Utopia) and PH (The Principle of Hope). Further details appear under Works consulted.

${ }^{12}$ This is conveyed by Bloch's remark on the latent truth of the great religions, also referred to as "abstract utopia": "The great humanity religions have often provided improper empty promises for the will to a better world, but they were for a long time also its most decorated room, its entire structure. In no longer abstract, in concretely-mediated utopia, as finally became clear with the image of death, this transcendence has, however, been removed: a devotion to human liberation and to that of its new space of existence [Daseinsraum] exists; outside this space there is no liberation" (PH 1181-1182).
} 
Bloch appears to be very ambiguous with regards to these questions. One can either argue that Bloch's thought on death is indicative of dialectical indifference, or one can argue that, on the contrary, Bloch's thought on death makes up part of his humanistic position. Let me briefly sketch the line of argumentation which could be followed in each of these cases.

In arguing that Bloch is fatalistic in his views on death and history, one would point to his seemingly crude allusion to the mythological figure "Chronos" who devours his own children. ${ }^{13}$ In addition to this, one would invert the meaning of - and turn against Bloch - his metaphorical phrase that "the jaws of death grind everything [die Kiefer des Todes zermalmen alles]" ${ }^{14}$ Bloch works with the metaphysical distinction between the kernel and the skin of being. While the skin refers to the existing state of reality and the human condition (in its unrealised possibilities) as it is at present (which Bloch refers to as "the That" [das Dass]), the kerne/ refers to the still undisclosed essence of reality ['the What']. This distinction is also important for Bloch's philosophical anthropology. The kernel of the human subject is still hidden and unconcealed inside the subject, announcing itself in the "darkness of the lived moment". ${ }^{15}$ Unlike the skin, the kernel of being does not share in the process of becoming and decay. When the kernel has been realised, existence will no longer be touched by death.

Now, in turning his allusion to Chronos and his metaphor of the "jaws of death" against Bloch, one could argue that Bloch, in effect, is glorifying death as the condition for the externalisation of the kernel of being. The "jaws of death", it would seem, grind away the skin of being until the kernel is set free. In this perspective one can both explain and make appear in a crude light Bloch's statement that death is "a setting-free precisely of the - exuberance of life", and that "in the content of death itself there is then no longer any death but the revelation of gained life-content, core content" (PH 1180).

\footnotetext{
${ }^{13}$ In $\mathrm{PH}$ (1178-1182), which is Bloch's most essential passage on death. "Chronos devours his children, for the authentic one is not yet born, the 'Stay awhile, you are so fair' has not yet appeared" (PH 1179). See PH (1181) for Bloch's further allusion to the myth of Chronos.

${ }^{14} \mathrm{PH}$ (1107). In the context of this quote, Bloch argues that "death is the great forwarding agent of the organic world - but to its catastrophe". The allusion to Chronos thus has a context of disapproval. However, one could deconstruct this passage in arguing that it conveys some of the darker aspects of Bloch's thought.

${ }^{15}$ In his early work The Spirit of Utopia, Bloch describes the anthropological background to his notion of the "darkness of the lived moment" as follows: "Here rests a seed which is indestructible, precisely the enfolded self, the darkness, the question, the meaning, the ground, the center of the self-encounter of us all, shadowy no less as still an act of consciousness than as an object of consciousness wanting to objectivate itself, and yet the very realest support of our personality" (SU 252-253).
} 
Further potential evidence that Bloch is indeed this crude in his position on death, one could argue, is the suggestion in a number of passages that with death what is essential to the subject merges into the cosmos. From a Levinasian perspective there seems to be something crude about this idea, because such a fusion with totality would imply disregard of the individual in his/her particularity. In the passage entitled "Dissolution in the universe, lethal return to nature" (PH 1148), ${ }^{16}$ Bloch shows appreciation of such ideas in a number of prominent eighteenth-century German authors, such as Gottfried Keller, Goethe and Hölderlin. Even the passage on metaphorical immortality in work ( $\mathrm{PH} 1161-1167)$ remains ambiguous. ${ }^{17}$ The ambiguity of humanism, on the one hand, and a mysticism of cosmic unity, on the other hand, is clearly noticeable in what Bloch claims with respect to Goethe. "Goethe ... imagined not only the cosmic survival of his essence but precisely also immortality in his work which had become historical and which would remain behind as historical" (PH 1163, italics added).

Bloch's texts, however, provides also for the possibility of a humane reading of his ideas on death, history and the meaning of work. For the purpose of such reading one would emphasise precisely Bloch's appreciation of the historical value of work. For the purpose of such reading it is also important that we read Bloch's statement that death is "a setting-free precisely of the - exuberance of life" (PH 1180) in a different perspective, and that we take into account his belief that in a humanised world death will lose its sting (PH 1174, 1182). Evidence that what is at stake in Bloch's reflections on death are not a glorification of death we already find in the fact that the title of the relevant chapter refers to death as "the strongest non-utopia" (PH 1103).

Bloch's contention that there is a humane content to death appears in a less crude light when we take into account his notion of "death as the chisel in tragedy" (PH 1167-1172). The death of the tragic hero, Bloch contends, defines his humanity. Bloch holds that "in well-depicted fictional characters the most important characteristic of human Being is preserved, namely the moral" (PH 1167). The tragic hero meets his death defiantly and he dies tragically and without consolation. The way in which the decisions of the tragic hero are caught up in an irreversible fate makes his heroism and refusal to die appear all the more sharply. In this sense "the tragic death works as a chisel" $\mathrm{PH}$ 1168). The bravery (non omnis confundar) with which the tragic hero meets

\footnotetext{
${ }^{16}$ Original German: "Auflösung ins All, letale Rückkehr zur Natur”.

${ }^{17}$ In his appreciative essays on Bloch, Levinas (GM 33-42, GTD 92-105) appears to be oblivious to the ambiguities in Bloch's position on death. He makes no mention of Bloch's mysticism of cosmic unity. Very selectively, he highlights the typically humanistic aspects of Bloch's position on death, and especially those aspects that enable him to find in Bloch an ally in his opposition to Heidegger.
} 
death constitutes his sole utopian moment: "[M]odern tragedy does not in the least imply a heaven. This is why the nature of the tragic-utopian deathconsolation could remain now that religious ideas have departed, with whose 'non omnis confundar' the receptivity to un-death in death even here is undoubtedly still filled" (PH 1171).

Reading also Bloch's appreciation of various religious (PH 1109) and post-religious ( $\mathrm{PH} 1142,1156)$ wishful images against death in a similar perspective seems plausible. The religious belief in life after death and the secular hope of immortality in one's work should be understood as expressions of the non omnis confundar. What the wishful images of the afterlife express is not a glorification of death. On the contrary, they express a refusal of the human subject to succumb in the face of death. Wishful images express precisely the sanctity of life and the beatitude of existence.

Precisely because of its capacity for positive astonishment ... there
lives in every phenomenology of non omnis confundar an
enigmatic, currently often not at all guaranteed joy; it arises from
great health, from the bottom right up to the top, and it gives space
to consciousness of a utopian aura in man.

(PH 1180)

This explains how death works as a "chisel" to define the best part of man. Also, it explains why Bloch holds that a victory over death is accomplished in astonishment. In positive astonishment the subject comes into contact with the inexpressible joy of existence. Bloch underlines the importance in this regard of experiences almost entirely insignificant in the public realm. In wonderment about, for example, an autumn leaf that flutters in the wind, the subject comes to be overwhelmed by a joy that exceeds the limited span of its lifetime:

Experiences are found which something which in all public contexts is almost irrelevant suddenly impresses, as if a first sight of the That were contained within it ... This may even be the way a leaf turns in the wind, but what is intended may also be filled with more familiar, higher contents. The smile of a child, a girl's glance, the beauty of a melody rising up from nothingness, the scornful flash of a strange word which does not seem rightly to belong anywhere.

(PH 1179)

In such moments the subject can be filled with a feeling Bloch describes as carpe aeternitatem in momento - seize all of eternity in the moment. 


\section{On history and salvation in Emmanuel Levinas and Ernst Bloch}

Bloch's special appreciation of mundane moments of astonishment are significant, because it indicates that as a dialectical thinker he allows for the unique existential experiences of the individual. In such moments of astonishment the subject refuses reduction to its place in the totality of history. This helps to shed some light on Bloch's valorisation of the work of life, because in these moments it is as if the subject suddenly catches sight of an unrealised promise in being. In a humane reading of Bloch one would stress that the life and death of the individual aren't sacrifices paid for the realisation of this promise within history. On the contrary, the subject from out of itself hopes that its work makes a contribution to the full realisation of this promise in being. In unique experiences of the joy of existence, the subject desires to still share in this joy even after its death. In this perspective one can say that the emotion non omnis confundar expresses a peculiar spirituality. In as much as this is a spirituality at the heart of a materialistic thinker, it indicates the richness of Bloch's humanism.

A humane reading of Bloch will finally emphasise on Bloch's belief that in a world where the humanum has been realised, death will lose its sting and, connected with this, Bloch's notion that the emotion with which the subject meets its own death is melancholy over its uncompleted work. Bloch holds that the kernel of being is extra-territorial to death $(\mathrm{PH} 1182)$. What this means is that death makes out part of the process of becoming and decay. The kernel is still unbecome [Ungeworden] ( $\mathrm{PH} 1182)$. Although the kernel is that which is driving forth in the process, it does not share in the process of becoming and decay. Consequently Bloch holds that when the kernel has been realised and turns out well (into an humanum), the process-character of reality will be transcended and existence will be extra-territorial with regards to death: "[T]he core of existing, if it had become and at the same time, when brought out, had turned out well, would in this achievedness be all the more extra-territorial to death; for this death itself would have become remote and extinct, along with the processual inadequacy of which it is part" (PH 1182). ${ }^{18}$ In a world where the humanum had been realised, the work of life would be complete and death will lose its sting (see also 1174-1175).

Undoubtedly there seems to be some religiosity (and an element of fantasy or wishful thinking) to Bloch's belief that in a humanised world the human subject will not be touched by death any longer. However, Bloch's narrative in this regard serves to convey the depth of his humanism. The disappointment with which the subject meets its own death follows from the fact that - in a still inhumane world - life's work is incomplete. What underlies the melancholy with which the subject meets its death is an unselfish concern

\footnotetext{
${ }^{18}$ See also Van Dongen (1972:55-60).
} 
with the well-being of the fellow human being. What this indicates is that, for Bloch, the individual is not left indifferent by the misery of his/her neighbour. Hereby Bloch underscores death as an incentive to emancipatory work. As Levinas remarks in one of his appreciative essays on Bloch: "What incites this revolutionary movement is the meaning of human misery ... The fulfilment of man is the fulfilment of being in its truth" (GDT 94).

Bloch's position on death and the work of life remains ambiguous. However, for the purposes of a present-day appreciation of his work, it seems more compelling to draw on the humanistic rather than the fatalistic aspects of his work, and that to explore the humane depth of his writings and metaphors.

\section{FECUNDITY, PATIENCE, AND INSTITUTIONAL JUSTICE: LEVINAS'S PERSPECTIVE ON SALVATION IN HISOTRY}

Levinas, in the end, is not content with Bloch's notion that the subject meets death with melancholy over the uncompleted work of life (GDT 106). Although this melancholy is derived from an underlying humane concern in the subject, the element of self-pity it entails gives us a clue as to why Levinas does not embrace Bloch's position. It is as if, in Bloch, the subject has pity on itself for the fact that it does not share in the realisation of the humanum. For Levinas death most primarily concerns the subject as the mortality of the neighbour. "[W]e emphasise the question raised by death in the nearness of the neighbour, a question that paradoxically is my responsibility for his death" (GDT 106). The movement in which the subject rises above death would have to be a movement towards the other.

For Levinas there are three perspectives in which the subject transcends death: patience, which represents a personal way; the realisation of the subjective will in just social institutions; and in biological fecundity. ${ }^{19}$ Fecundity accomplishes a synthesis of the first two perspectives, since it guarantees a concrete realisation of goodness in being (TI 247) where at the same time the personal identity of the "I" remains preserved ( $\mathrm{TI} 269,300)$. Moreover, fecundity takes the place that the philosophy of history occupies in the dialectical tradition. ${ }^{20}$ Hereby Levinas undermines the all-encompassing closure of Hegelian dialectical system. Characteristic of fecundity is that it introduces a future which is novel and that cannot be captured in, or reduced to, an all-encompassing synthesis.

\footnotetext{
${ }^{19} \mathrm{I}$ borrow this insight from a translator's footnote of Theo de Boer to the Dutch translation of Totality and infinity ( $\mathrm{TeO} 279$ ).

${ }^{20}$ See De Boer's footnote (TeO 293) and $\mathrm{TI}(247,306)$.
} 
Levinas develops all three these notions - patience, the realisation of justice, and fecundity - in the light his understanding of time as the condition for the possibility of repair. ${ }^{21} \mathrm{He}$ dismisses the traditional hierarchy of time and eternity, where time is always regarded as inferior (GDT 93; see also EE 91). For Levinas time itself constitutes the relationship with the infinite. As the "unlimited infinity of the future" ( $\mathrm{TI} 282$ ), time provides for the possibility of pardon, recommencement and repair.

The infinity of time does not have a linear character; it does not form a continuum. Levinas understands time as diachronic, where moments succeed each other in time, and each instant has a novel quality, such that discontinuity is allowed for within the infinity of time. This discontinuity of time can best be understood by analogy to parenthood (or "paternity" in Levinas's vocabulary). In bringing a child into the world one produces a future over which one does not have complete control, where one's powers of existence bring forth something that escapes one's powers and marks an interruption of it. "Without multiplicity and discontinuity - without fecundity - the I would remain a subject in which every adventure would revert into the adventure of a fate". 22

Let us now look in closer detail at Levinas's phenomenological notions of fecundity and parenthood, patience and institutional justice.

\subsection{Fecundity and parenthood}

Levinas's phenomenology of the erotic relationship and fecundity receives its riches nuances in his mature work Totality and infinity (254-285), but an anticipation of its significance for his thought is noticeable in his two early works Existence and existents (43-44) and Time and the Other (8-94).

The reason why Levinas attributes special importance erotic love, fecundity and parenthood is that all these movements entail an eschatological moment. What "eschatological" here means is that they entail anticipation of, and contain reference to, a moment which resides in the inner-worldly future, beyond the horizon of established reality. The importance assigned to eschatology results from Levinas' tragic view on death. Death is tragic, because if there is to human existence no more than finitude, then the subject remains subordinate to the indifference of history and the anonymous reign of the there is (see $\mathrm{TI} 232-236$ ). Levinas takes seriously the desire inside the human subject to overcome this tragic character of finite existence.

\footnotetext{
${ }^{21}$ The section "The infinity of time" (TI 281-285) is relevant.

${ }^{22} \mathrm{TI}$ (282). See also $\mathrm{TI}$ (301), and (269): "[In fatherhood] being is produced as multiple and as split into same and other; this is its ultimate structure. It is society; and hence it is time".
} 
The eschatological significance of what Levinas calls in Totality and infinity "The ambiguity of love" (TI 254-255) and "The phenomenology of eros" (TI 256-269) is elucidated against the horizon of individual mortality:

[W]e must indicate a plane both presupposing and transcending the epiphany of the Other in the face, a plane where the I bears itself beyond death and recovers also from its return to itself. This plane is that of love and fecundity, where subjectivity is posited in function of these movements.

Levinas expresses hope that the subject will overcome the tragedy of its own finitude and, at the same time, not be returned to the self-same and identical realm of its solitary existence. Erotic love contains this possibility. This is what the hesitant movement characteristic of the caress phenomenologically signifies:

The caress is a mode of the subject's being, where the subject who is in contact with another goes beyond this contact. Contact as sensation is part of the world of light. But what is caressed is not touched, properly speaking...The caress does not know what it seeks ... The caress is the anticipation of this pure future [avenir], without content.

(TO 89)

The analysis in Time and the Other of the movement transcending the realm of light is elaborated in Totality and infinity as an anticipation of a still unrealised future: "Beyond the consent or resistance of a freedom the caress seeks what is not yet, a 'less than nothing', closed and dormant beyond the future, consequently dormant quite otherwise than the possible, which would be open to anticipation" (TI 258).

Erotic tenderness, pehnomenologically seen, constitutes a prereflective anticipation of an "eschaton" which resides beyond the present horizon, but yet, within the world. The eschatology and promise of erotic love extends to fecundity ( $\mathrm{TI} 274$ ), and also to paternity and filiality ( $\mathrm{TI} 278$ ). According to Levinas, the child (or the "son" [fils] in his terminology) is the "eschaton" which is anticipated in the erotic caress. The unborn child can be considered an "eschaton" in three respects: the child is not yet existing, the possibility of its existence resides in the future, and the child's existence is to be realised within the world. "In fecundity the I transcends the world of light not to dissolve into the anonymity of the there is, but in order to go further than 


\section{On history and salvation in Emmanuel Levinas and Ernst Bloch}

the light, to go elsewhere" (TI 268). In fecundity Levinas finds a movement that entails both promise and consolation, as it enables the subject to overcome its own finitude and mortality.

Hereby Levinas finds the answer to a number of philosophical problems he has identified. He sets out to defend a metaphysical pluralism of the human subject ( $\mathrm{TI} 232$ ). In order to do so, he needs to reject all belief in the immortality of the soul. With belief in the immortality of the soul such pluralism is not possible, since such belief implies, first, a prolonged egoism, and secondly, the recuperation of individual subjects into an all-incorporating totality. To defend his understanding of a pluralism of subjects, Levinas stresses the corporeity and mortality of human subjectivity (TI 232). Erotic love, fecundity and filiality are movements that derive their meaning precisely from corporeity and mortality. In filiality, both egoism and the necessity for belief in an all-encompassing totality are overcome.

In one's child one rises above one's own finitude and mortality, "for the I is its child" (TI 278). Already in Time and the Other Levinas has emphasised that the relation to one's children cannot be described in terms of possession, and also that one's children are much closer to one than simple possessions: "I do not have my child, I am in some way my child" (TO 91). Consequently one continues to exist in one's child. As Visker (2003: 88) explains: "Through the child the man becomes father and the woman mother. In other words, the self is not completely destroyed, but has been transformed in its essence" (my translation).

The critical reader may feel tempted to ask whether this doesn't represent another form of prolonged egoism. Levinas maintains that this is not the case, because the connection in a parent-child relationship is one of creation rather than causality ( $\mathrm{TI} 279$ ). Rather than being a prolonged egoism, fecundity and parenthood help to unite two contradictory movements: "The son resumes the unicity of the father and yet remains exterior to the father: the son is a unique son" ( $\mathrm{TI} 279$ ). Fecundity constitutes an ability in the subject to bring forth something that transcends and falls outside the control of the subject. Consequently it introduces discontinuity into its existence. "The relation with the child - that is, the relation with the other which is not a power, but fecundity - establishes relationship with the absolute future, or infinite time" (TI 268).

The significance of Levinas's phenomenoligal analyses of fecundity and parenthood extends metaphorically. "Biological fecundity is but one of the forms of paternity. Paternity, as primordial effectuation of time, can, among men, be borne by biological life, but be lived beyond that life" (TI 247). As metaphors, paternity and fecundity are important for Levinas's understanding 
of time as discontinuous, and the condition for the possibility of repair. As Bouckaert remarks: "Through the child the past loses its definite character. In this perspective, Levinas (1976:61, my translation) regards time as forgiveness, as possibility to renew the past radically."

We find a limited exploration of the metaphorical meaning of paternity in Levinas's explanation of the transition from filiality to fraternity ( $\mathrm{TI} 278$ 280). Fecundity constitutes not only a capacity in the 'l' to survive itself. The "father-son" relation also constitutes the singularity of the ' $l$ '. Father and son are bonded in their relationship without first choosing one another. "[The] relation of the father with the son is not added to the already constituted I of the son, as a good fortune. The paternal Eros first invests the unicity of the son ... [The son] is unique for himself because he is unique for his father" (TI 279).

Now, in this unique relation between parent and child Levinas indicates a transition that results in one of the most intricate ambivalences in his work. In one's child one discovers an extension and prolongation of oneself but, in as much as one becomes essentially transformed in one's child and do not have full control over him/her, one can be confronted in one's child also with a stranger. Thus, "[t]he unique child, as elected one, is accordingly unique and non-unique" and "these relations free themselves from their biological limitation" (TI 279). As Oliver (2005:311) explains, "for Levinas, the promise of paternity is a promise not [only] of recognition but of nonrecognition, of strangeness, of an open future, of infinity of singularity." Now, the bond between parent and child becomes interrupted and is moved to another plane when one takes into account the social aspect of the parent-child relationship. The parent-child relationship then exceeds the confines of its initial biological and erotic significance when the child shows him/herself to the parent by his/her "face": "[T]hese relations free themselves from their biological limitation. The human I is posited in fraternity: that all men are brothers is not added to man as a moral conquest, but constitutes his ipseity. Because my position as an I is effectuated already in fraternity the face can present itself to me as a face" (TI 279-280). Just as the parent-child relationship is not limited to its biological aspect, but includes also a social aspect, the consolatory meaning of paternity also has a wider metaphoric and symbolic significance.

The appreciation that Levinas expresses for Bloch's valorisation of life's work (GDT 95) serves as a further indication of the possible metaphoric significance contained in Levinas's phenomenology of parenthood. Bloch values the modern secular idea that one survives in one's works and finds consolation against death in them: "No man, says the peasant proverb, should leave this life without having planted a tree, left behind a son. Children take 


\section{On history and salvation in Emmanuel Levinas and Ernst Bloch}

the name of their father, and the father wishes that they should continue to be his work. But works of the mind are also called children, works that have been painted, composed, written built, thought" (PH 1161-1162). In Bloch the ideal of a universal brotherhood of men is so prevalent that intellectual parenthood attains a symbolic value that does not enter into any significant conflict with biological parenthood. Both have the capacity to contribute to the building of human history and society.

Visker (1999) points out that Levinas's attempt to provide parenthood with a metaphorical meaning inevitably enters into conflict with the value he attaches to biological parenthood:

[O]ne need only to think of the difference between my biological children and my intellectual children ... to realize that it is perhaps no coincidence that Levinas should be downplaying here the importance of [the] possessive pronoun which points to what is beyond the symbolic in paternity. No matter how other my children may turn out to be, even when they have become so other that I can in no way recognize the slightest trait of myself in them, I can and will still find consolation in the thought that they are my own, my flesh and blood and that they bear my name.

(Visker 1999:342)

Although Levinas perhaps does underestimate the tension between the singular and the universal in his analyses of parenthood, one can appreciate its most significant contribution in light of his idea of ethical universality. While the "relation with the face in fraternity, where in his turn the Other appears in solidarity with all others, constitute the social order" ( $\mathrm{TI} 280$ ), erotic love and fecundity open a perspective on the ethical universality of time, as the possibility of forgiveness, renewal and repair. "[T]he erotic and the family which articulate [social life] ensure to this life, in which the I does not disappear but is promised and called to goodness, the infinite time of triumph without which goodness would be subjectivity and folly" (TI 280).

\subsection{Patience}

Patience constitutes a second perspective in which the subject asserts itself in the face of the indifferent march of history. Three texts are especially indicative of Levinas's thinking on patience: the essay entitled "The virtues of patience" (DF 154-155), Totality and infinity (232-240) and God, Death and time (106-117). The ideas presented in these texts show a coherent relation to each other, but cover diverging aspects of the theme. 
In "The virtues of patience" Levinas explains the significance of patience in a cultural-historical perspective. Modernity, he argues, has given rise to an ethos of heroism. This is clear from the tendency to "glorify whatever is harsh and pitiless, adventurous and heroic, dangerous and intense" (DF 155). Magnanimous deeds, and projects that can be implemented rapidly are appreciated, while caution is dismissed of as a form of cowardice. This modern cult of magnanimity has given rise to a justification of brutality, where "[violence] puts itself forward as the path to grace" (DF 154). Levinas concludes that "[t]he modern world has forgotten the virtues of patience" (DF 155).

This dismissal of heroism and magnanimity should not be misunderstood as "resignation in the face of revolutionary spirit" (DF 155). Levinas explicitly points to the connection between patience and the revolutionary spirit. Thus, Levinas's invitation for us to rediscover the virtues of patience should not be misunderstood as if it were quietism in the face of social reality. Rather, patience entails that we ought to persevere in a selfcritical awareness in our pursuit of ideals. ${ }^{23}$ Patience entails a willingness to suffer for a good cause. "The hand that grasps the weapon must suffer in the very violence of that gesture. To anaesthetize this pain brings the revolutionary to the frontiers of fascism" (DF 155). It entails the circumspection that will help us to prevent patience and perseverance from turning into impatience.

Totality and infinity emphasises patience as the subject's capacity to endure suffering and to place death at a distance. Levinas indicates in his early work how suffering can strip the subject of its initiative and as such it marks a limit to the subject's mastery over existence. Now, patience as the perseverance of the subjective will in the face of suffering is a way in which the subject prolongs its mastery over existence. "The being that does violence to me and has a hold on me is not yet upon me; it continues to threaten from the future" (TI 239). Patience preserves a temporal distance between the subjective experience of suffering and the possibility of extreme relinquishment (death).

Paradoxically, the egoistic self-perseverance in patience has, at the same time, an ethical significance. The subject suffers and perseveres in spite of itself so that "the will breaks through the crust of its egoism and as it were displaces its center of gravity outside itself, to will as Desire and Goodness

\footnotetext{
${ }^{23}$ See also TI (236): "In affirming that the human will is not heroic we have not declared for human cowardice, but have indicated the precarity of courage, always on the verge of its own failure ...."
} 


\section{On history and salvation in Emmanuel Levinas and Ernst Bloch}

limited by nothing" ( $\mathrm{TI} 239$ ). The postponement of extreme relinquishment allows one time to be for the other; time for servitude, and for hope.

Precisely this ethical dimension of patience is radicalised in God, death and time. The emphasis is not so much any longer on physical suffering whereby the subject finds itself "backed up to being" (TI 238) and confronted with the imminence of death in suffering. The emphasis shifts to suffering as ethical suffering, the self suffering on behalf of the other, as the "disquiet [that] disturbs the heart at rest" (GDT 111). Here patience is connected to Levinas's notion of the passivity of responsibility. The trace of the Good that 'creation' has left behind in the subject, marks the subject with a pre-reflective openness that makes him/her susceptible to the appeal of the fellow human being. Because of this pre-reflective openness to the other the self is "suffering an assignation without possible evasion" (GDT 111).

In perspective of the infinitude of time, patience takes on its ethical significance. Within the diachrony of time, which means that moments dissimilar in value infinitely succeed one another, an infinitisation of responsibility explodes into the same: "The Same containing more than it can contain - that is Desire, searching, patience, and the length of time" (GDT 116).

As endurance of the length of time, patience contains also an eschatological moment. The notion of patience entails a servitude which is without reward, and this once more enables Levinas to invert the traditional notion of eschatology. "The patience and endurance of the beyond-measure, to-God [à-Dieu]" involves an "awaiting without an awaited object" (GDT 115). What this means is, first, that within patience the hope is preserved for the capacity of time to fulfil the work of repair, and, second, the Messianic awaiting does not exempt the subject from its responsibilities. As Catherine Chalier (1998: 289) summarises it: "[T]he much awaited Messiah does not... play the role of national saviour but rather, in perhaps a more urgent fashion, that of a redeemer of individual souls, of a spiritual guide toward this light of the Infinite within oneself and outside oneself".

\subsection{The subjective will and institutional justice}

The third perspective in which the subject transcends death is that of the realisation of the subjective will in an order of institutional justice. ${ }^{24}$ We have seen that, initially, Levinas is sceptical of a valorisation of the work of life. The subject refuses to be identified with its work and refuses to be absorbed into the totality of history. Patience allows the subject a movement towards the other, where it is not made subservient to the totality of history. Now, the

\footnotetext{
${ }^{24}$ The section "The truth of the will" (TI 240-247) is especially relevant.
} 
space that patience allows for the subjective will eventually means that the will is redirected toward the objective order of social institutions. We thus notice a counter-movement of the will: initially it seeks for seclusion and is sceptical about work, but eventually the will does seek some value in the objective expression of work. "The will seizes upon the other chance in the time left to it by its being against death: the founding of institutions in which the will ensures a meaningful, but impersonal world beyond death" (TI 236).

What gives rise to this counter-movement of the will? First, the will seeks to realise the true vocation of responsibility in the just social order (TI $236,242,247)$. Second, in such concretisation of goodness, the will finds confirmation against death (TI 240-241). Confirmation against death is needed, because in apology the self still "lays itself open to the violence of death" (TI 242). Where the good will of the subject becomes realised in the social order, institutions and the law, the singularity of the I is confirmed, and works of the subject find an expression that exceeds its own lifetime. "The person is thus confirmed in objective judgement and no longer reduced to his place within the totality" ( $\mathrm{TI} 246)$.

Herein one can notice Levinas's insistence that the Good has to be concretised within being. Initially the Good is transcendent to being and distinct from it. However, with its concretisation in social institutions, the Good has a chance to get a concrete foothold in being and to gain immanence in being. As Levinas explains: "The invisible must manifest itself if history is to lose its right to the last word" (TI 243). The concretisation of institutional justice provides the human with the chance to rise above the indifference of history. "Hence freedom would cut into the real only by way of institutions" (TI 241).

The realisation of justice is the true vocation of responsibility. However, also in the founding of humane history, a tension between history and the human individual remains recognisable and extends to what Levinas calls the tension between ethics and justice. Levinas asks for our vigilance with regards to the impersonal character that the social order inevitably tends to take on. "[P]olitics left to itself bears a tyranny within itself" (TI 300). We thus notice a return of the initial cynicism with regards to the work of life. "[T]he will knows another tyranny: that of works alienated, already foreign to man, which reawaken the ancient nostalgia for cynicism. There exists a tyranny of the universal and of the impersonal, an order that is inhuman though distinct from the brutish" (TI 242). What is required is vigilance with respect to the institutional order, so as to guard cautiously that the institutional order does not take on a life of its own. The concretisation of responsibility in justice represents a movement of ethics towards ontology. Justice (the impersonal 
order) needs to be constantly corrected with reference to ethics (the interpersonal relationship). Justice must remain under the auspices of the Good. "[Justice] knows that it is not as just as the goodness that instigates it is good. But when it forgets that, it risks sinking into a totalitarian or Stalinist regime, and losing, in ideological deductions, the gift of inventing new forms of human coexistence" (RB 206/EN 230).

I would like to conclude this article with a remark on the ontological significance of Levinas's conception of justice. This brings us to what can be described as the "extra-moment" of Levinas's theory of ontology, which is to say, his notion of the interconnectedness of ontology and ethics accomplished in the interpersonal relationship.

A first significance of the extra-moment we find in Levinas's notions of the interconnectedness of being and the Good in the interpersonal order. Significant in this regard are the notion in his early work that sociality is time (EE 93), the notion in his mature work that the face of the other is as the original signifier at the origin of light without itself appearing in the light ( $\mathrm{TI}$ 261 ), and the notion in his latter work that the foundation of consciousness is justice (OB 160). This first aspect of the extra-moment of Levinas's ontology is already captured and expressed in the following enigmatic phrase: "Meaning signifies in justice [La signification signifie dans la justice]" (OB 158). ${ }^{25}$

Still, this phrase seems to convey something more. What is of significance in this regard is that this phrase has as its context the passage where Levinas expresses his dream of a just society (OB 153-165). There Levinas develops the notion of the state and of justice as derived from proximity. ${ }^{26}$ In this perspective the enigmatic phrase above would compel one to the following interpretative, rather than semantic, translation: In the just social order, meaning would be the meaning of justice, which is to say, behind all meaning we would rediscover the work of justice. ${ }^{27}$ A society "in which being, totality, the State, politics, techniques, work" do not have "their center

\footnotetext{
${ }^{25}$ The English translation of Alphonso Lingis is "Signification signifies in justice". In this particular context, however, it seems more appropriate to translate "la signification" as "meaning" rather than "signification". "Meaning" conveys more effectively the idea of a horizon of intelligibility. One should note that Levinas also points out that the advent of rationality in ethics implies that 'meaning' escapes definition: "It is phenomenologically irreducible: meaning signifies. To seek a definition of meaning is like attempting to reduce the effect of a poem to its causes" (RB 221).

${ }^{26}$ On this theme, see also the interview from 1988, "The Other, Utopia and Justice" (RB 200210/EN 223-233).

${ }^{27}$ Although OB (158) is usually read in the light of Levinas's explanation of consciousness, the passage also seems to allow being read from the perspective of the interconnectedness of being and the Good in Levinas's understanding of the social relationship. See also Terreblanche (2007:320-321) in this regard.
} 
of gravitation in themselves" (OB 159) will set in motion an incarnation of the Good in being. That would also realise the deepest meaning of Levinas's claim that "it is for justice that everything shows itself" ${ }^{28}$

\section{Works consulted}

Bloch, E [1959] 1986. The principle of hope, tr by N Plaice, S Plaice \& P Knight. Cambridge, MA: The MIT Press.

Bloch, E [1923] 2000. The spirit of Utopia (1923), tr by A Nassar. Stanford, CA: Stanford University Press.

Bouckaert, L 1976. Emmanuel Levinas: Een filosofie van het gelaat. Nijmegen: Uitgeverij B Gottmer.

Burggraeve, R 1986. Mens en medemens, verantwoordelijkheid en God: De metafysische ethiek van Emmanuel Levinas. Leuven: Uitgeverij Acco.

Chalier, C [1989] 1998. The Messianic Utopia, tr by A Slade. Graduate Faculty Philosophy Journal 20(2-21:1), 281-296.

Finkielkraut, A [1984] 1997. The wisdom of love (La sagesse de l'amour), tr by $\mathrm{K}$ O'Neill \& D Suchoff. Lincoln, NE: University of Nabraskar Press.

Levinas, E [1961] 1969. Totality and infinity: An essay on exteriority, tr by A Lingis. The Hague: Martinus Nijhoff Publishers.

Levinas, E [1947] 1978. Existence and existents, tr by A Lingis. The Hague: Martinus Nijhoff Publishers.

Levinas, E [1947] 1981. Otherwise than being or beyond essence, tr by A Lingis. The Hague: Martinus Nijhof Publishers.

Levinas, E [1947] 1987. Time and the Other, tr by R A Cohen. Pittsburgh, PA: Duquesne University Press.

Levinas, E [1961] 1987. De totaliteit en het Oneindige: Essay over de exterioriteit, tr by Th de Boer \& Ch Bremmers. Den Haag: Matinus Nijhoff Publishers.

Levinas, E [1963] 1990. Difficult freedom: Essays on Judaism, tr by S Hand. London: Athlone.

Levinas, E [1986] 1998. Of God who comes to mind, tr by B Bergo. Stanford, CA: Stanford University Press.

Levinas, E [1995] 1999. Alterity and transcendence, tr by M B Smith. London: The Athlone Press.

Levinas, E [1991] 1999. Entre Nous: On thinking-of-the-Other, tr by M B Smith \& B Harshav. New York: Columbia University Press.

Levinas, E [1993] 2001. God, death, and time, tr by B Bergo. Stanford, CA: Stanford University Press.

Levinas, E 2001. Is it righteous to be? Interviews with Emmanuel Levinas, J Robbins (ed). Stanford, CA: Stanford University Press.

Oliver, K 2005. Fatherhood and the promise of ethics, in Claire Katz \& Lara Trout (eds), Emmanuel Levinas: Critical assessments of leading philosophers. Vol IV, Beyond Levinas, 307-324. London: Routledge.

\footnotetext{
${ }^{28}$ OB (161). Original French: "c'est pour la justice que tout se montre".
} 
Terreblanche, S 2003. Die melancholie van die lewenswerk - Arbeid, hoop en vertroosting in die utopiese denke van Ernst Bloch. Fragmente - Tydskrif vir Filosofie en Kultuurkritiek 10 \& 11, 5-27.

Terreblanche, S 2007. Todorov, Levinas and Anti-Totalitarian Humanism: A perspective on contemporary utopian thought, HTS 63(1), 301-325.

Van Dongen, W T A M 1972. Het denken over de dood in het Marxisme van Ernst Bloch. Een anlytisch-kritische studie rond de exterritorialiteit. Stichting Theologische Faculteit Tilburg: Ongepubliceerde doctorale proefschrift.

Visker, R 1999. Truth and singularity - Taking Foucault into phenomenology. Dordrecht: Kluwer Academic Publishers.

Visker, R 2003. De Goede Ander: hoe vreemd is de multicultirele Ander?, in L Jansen \& A Oudejans (Reds), De Vreemdeling, 87-107. Budel: Damon. 